\title{
General Characteristics of Surface Waves off Port Said, Egypt
}

\author{
M.S. Elsharkawy ${ }^{1}$, T.M. El-Geziry ${ }^{1}$, S.H. Sharaf El-Din ${ }^{2}$ \\ ${ }^{I}$ (Physical Laboratory, National Institute of Oceanography and Fishery,EGYPT) \\ ${ }_{2}^{2}$ (Oceanography Department, Faculty of Science, University of Alexandria, EGYPT)
}

\begin{abstract}
This paper preliminarilyinvestigated the general characteristics of off shore and near shore windgenerated surface waves over a period of six months (August- 1999 - February 2000) off Port Said, Egypt. It presented an analysis of the data measured using directional wave buoys moored at two locations: off shore $(133 \mathrm{~m})$ and near shore $(8 \mathrm{~m})$. Over the period of investigation, the study revealed a weak correlation coefficient $(0.28)$ between the offshore surface wave direction and wind direction. The mean of the former parameter was $245.8^{\circ} \mathrm{TN}$, while the mean of the latter parameter was $163.7^{\circ} \mathrm{TN}$. On the other hand, both off shore and near shore surface wave significant heights $\left(H_{s}\right)$ were highly correlated to the wind speed with coefficients of correlation as high as 0.72 and 0.53 , respectively. Also, the average $\left(H_{s}\right)$ was $1.6 \mathrm{~m}$ and $0.51 \mathrm{~m}$ for the off shore and near shore surface waves, respectively. The average mean zero-crossing period $\left(T_{z}\right)$ was $4.3 \mathrm{~s}$ and $5.3 \mathrm{~s}$ for the off shore surface waves and the near shore surface waves, respectively.
\end{abstract}

Keywords: Egyptian Mediterranean coast, surface waves, wave field data,windregime

\section{Introduction}

The primary mechanism controlling atmosphere-ocean interactions depends mainly on the air masses intrusion or replacement over the water basin through the transfer of heat, moisture and momentum at the sea surface $[1,2]$. Oceanic surface waves are preliminary produced by the circulation patterns associated with the stress exerted by air masses (winds) over the sea surface [3]. Changes in wave characteristics at any location can be attributed to many factors, among which are changes in the remotely-generated swells and changes in the local wind systems [4].

Information on the characteristics of the surface waves generated by the prevailing wind regime is of great importance for a wide range of applications from both environmental and engineering points of view. This includes, but is not limited to, calculations of wave loads on coastal structures; calculations of sediments and pollutants transports in coastal areas, real time swell forecasting, safety of maritime transportation, fishing industry, validation of wave prediction models [5-9].Surface waves have very complex natures and are highly irregular with respect to their height, direction, amplitude and period [10]. The direct measurements of these parameters are now carried out either by directional or non-directional instruments such as wave buoys or bottom-mounted acoustic Doppler transceivers. Moreover, nowadays there are different approaches to simulate and to predict the wind driven surface wave characteristics. These include statistical techniques, discrete spectral approach, stochastic simulation and numerical methods [11-15]

Several investigations were carried out on the investigation of surface waves propagation along the northern Egyptian Mediterranean coast. The research activity in this discipline targeted environmental issues asthe protection of coasts against erosion, and the investigation of vulnerability of the coast to the problems of the Sea Level Rise (SLR) and climate change [16, 17]. Surface wave research activities have suffered from the limitations of field measurements and scarcity of data records along the Egyptian Mediterranean coast. The aim of this study was to investigate the basic features of the propagation of wind driven surface waves off theEgyptian Mediterranean coastal city: Port Said.This was accomplished by the analysis of the six surface wave parameters: $\mathrm{H}_{\mathrm{s}}, \mathrm{T}_{\mathrm{z}}$, wave peak period $\left(\mathrm{T}_{\mathrm{p}}\right)$ maximum wave height $\left(\mathrm{H}_{\max }\right)$, maximum crest elevation $\left(\mathrm{C}_{\max }\right)$, and directional spread $(\Theta)$ for a period of six months (Aug-99 to Feb-00). Also, the wind speed and direction was analyzed by constructing wind roses, and frequency classes for the wind observations over a period of one year (Feb-99 to Feb-00).

\section{Materials}

Fugro Global Environmental and Ocean Sciences (Fugro GEOS) undertook a one year-long field measurement in front of the Eastern Egyptian Mediterranean coast, between February 1999 and February 2000. The aim was to collect data sets on current, waves, meteorology and hydrography; in order to be used for simulation and design purposes. The surface wave buoys and the meteorological station, used in the present work, occupied three locations:

1. Off shore wave buoy $\left(31.85^{\circ} \mathrm{N} ; 32.42^{\circ} \mathrm{E}\right)$ where the water depth is $133 \mathrm{~m}$

2. Near shore water wave buoy $\left(31.38^{\circ} \mathrm{N} ; 32.11^{\circ} \mathrm{E}\right)$ where the water depth is $8 \mathrm{~m}$

3. Meteorological station $\left(31.7167^{\circ} \mathrm{N} ; 32.4083^{\circ} \mathrm{E}\right)$.

DOI: $10.9790 / 2402-100802109115$

www.iosrjournals.org

$109 \mid$ Page 
All three stations,as shown in Fig. (1), are located in front of the Mediterranean coastal city: Port Said, Egypt

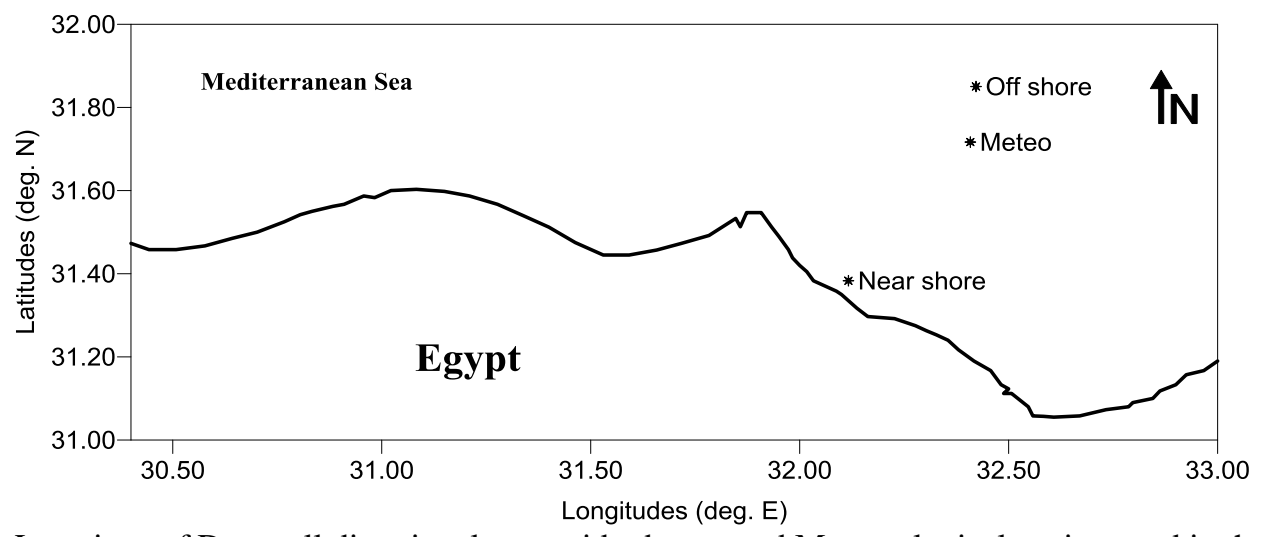

Figure1: Locations of Datawell directional wave rider buoys and Meteorological station used in the present study

Two simultaneous surface wave data sets, measured using Datawell directional wave rider buoys, were used in the present study. The recording dates extend to cover the period of six months from $06^{\text {th }}$ August 1999 to $09^{\text {th }}$ February 2000. While the off shore surface waves were recorded based on 120 minutes time-interval, the near shore ones were based on 90 minutes time-interval.For both near shore and off shore surface waves, all six parameters: $\mathrm{H}_{\mathrm{s}}, \mathrm{T}_{\mathrm{p}}$ and $\mathrm{T}_{\mathrm{z}}, \mathrm{H}_{\max }, \mathrm{C}_{\max }$, and $\Theta$ were obtained from the recorded data sets.

On the other hand, the meteorological parameters (wind speed and direction) at the area of investigation were recorded over one year (Feb 99 - Feb 00) based on 10 minutes time-interval. The meteorological records were missed during September 1999 due to an instrumentalmalfunction. Hence, the data for this month was interpolated linearly between August 1999 and October 1999.

\subsection{Wind Regime}

\section{Results and Discussions}

Over one year of records, the wind speed varied between calm $(0.1 \mathrm{~m} / \mathrm{s})$ to strong $(20 \mathrm{~m} / \mathrm{s})$, with an average wind speed of $5.3 \mathrm{~m} / \mathrm{s}$. The monthly mean wind speed (Table 1) varied between $3.2 \mathrm{~m} / \mathrm{s}$ and $6.8 \mathrm{~m} / \mathrm{sec}$ during August 1999 and January 2000, respectively. Fig.(2 \& 3) showed the hourly wind rose and the hourly wind speed class frequency distributions, respectively, over the period of survey (Feb-99 to Feb-00). The dominant wind direction was the NNW-N, and the dominant wind speed class was $3.6-5.7 \mathrm{~m} / \mathrm{s}$, with $33.96 \%$ and $34.1 \%$ percentages of occurrence, respectively.

Table 1:Summary of the monthly meteorological parameters from Feb-99 to Feb-00

\begin{tabular}{|l|l|l|l|}
\hline & \multicolumn{3}{|c|}{ Wind Speed (m/s) } \\
\hline & Mean & Min & Max \\
\hline Feb-99 & 5.3 & 0.0 & 16.9 \\
\hline Mar-99 & 5.4 & 0.0 & 14.1 \\
\hline Apr-99 & 4.7 & 0.0 & 12.2 \\
\hline May-99 & 4.2 & 0.0 & 12.6 \\
\hline Jun-99 & 4.6 & 0.0 & 10.1 \\
\hline Jul-99 & 4.5 & 0.0 & 10.3 \\
\hline Aug-99 & 3.2 & 0.0 & 7.0 \\
\hline Sep-99 & 3.8 & 0.0 & 0.0 \\
\hline Oct-99 & 4.5 & 0.0 & 12.1 \\
\hline Nov-99 & 4.9 & 0.0 & 11.2 \\
\hline Dec-99 & 5.5 & 0.0 & 14.5 \\
\hline Jan- 00 & 6.8 & 0.0 & 14.7 \\
\hline Feb-00 & 4.9 & 0.0 & 14.3 \\
\hline
\end{tabular}




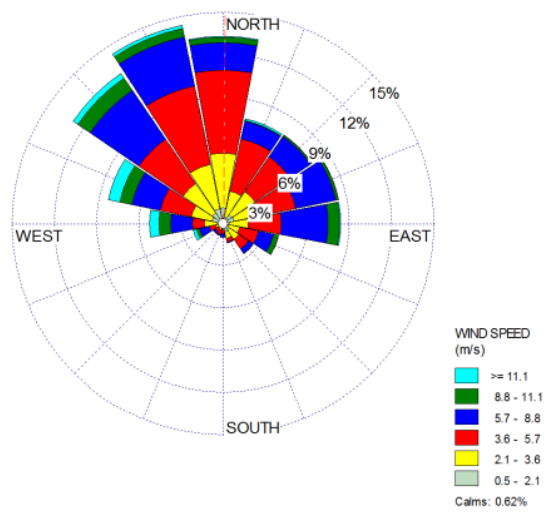

Figure 2: Hourly wind rose in front of Port Said, Egypt during the period February 1999 - February 2000

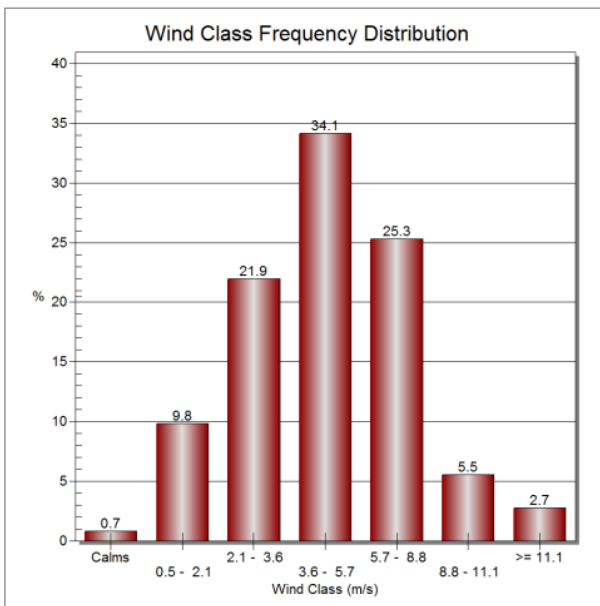

Figure 3: Hourly wind class frequency distribution off Port Said, Egypt during the period February 1999 February 2000

\subsection{Off shore surface waves}

Over six months of records (August 1999 - February 2000) off the coastal Mediterranean city: Port Said, the highest $\left(\mathrm{H}_{\mathrm{s}}\right)$ was $4.07 \mathrm{~m}$ and the lowest was $0.18 \mathrm{~m}$, with an average of $1.01 \mathrm{~m}$ over the study period (Fig. 4). This is in good agreement with the average $\mathrm{H}_{\mathrm{s}}$ for the surface waves measured at $12 \mathrm{~m}$ depth in front of

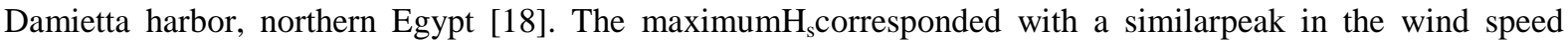
duringwinter (December 1999-January 2000) which were the months of the highest monthly mean wind speed and highest maximum wind speed as shown in Table 1 . The correlation coefficient between the two parameters $\left(\mathrm{H}_{\mathrm{s}}\right.$ and wind speed) was 0.72 , which reflected the strong tie between them.

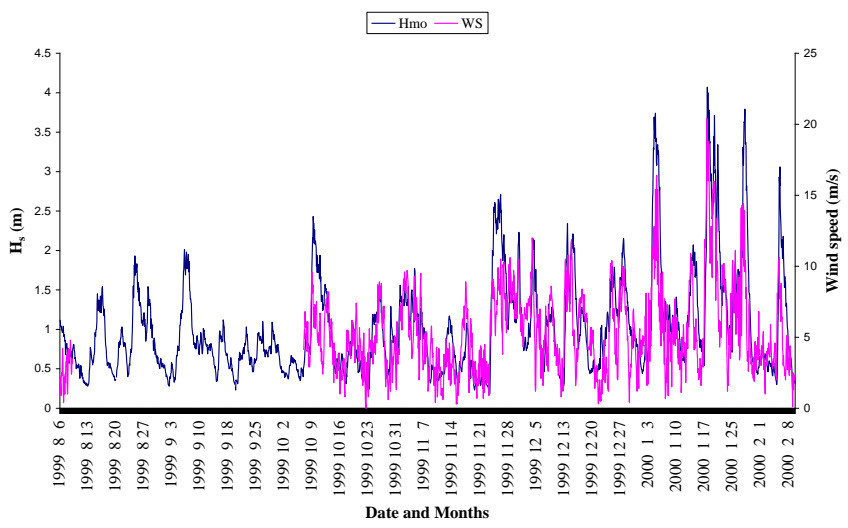

Figure 4: Time series plot of off shore significant wave height and the wind speed during the period August 1999 - February 2000 
Fig. (5) depicted the temporal distribution of both $\left(\mathrm{T}_{\mathrm{p}}\right)$ and $\left(\mathrm{T}_{\mathrm{z}}\right)$ wave periods. The wave peak and mean periods ranged from $1.75 \mathrm{~s}$ to $12.5 \mathrm{~s}$ and from $2.28 \mathrm{~s}$ to $7.68 \mathrm{~s}$, respectively. Over the six months of investigation (Aug-99 to Feb-00), the average $T_{p}$ was $6.3 \mathrm{~s}$ and the average $T_{z}$ was $4.3 \mathrm{~s}$.

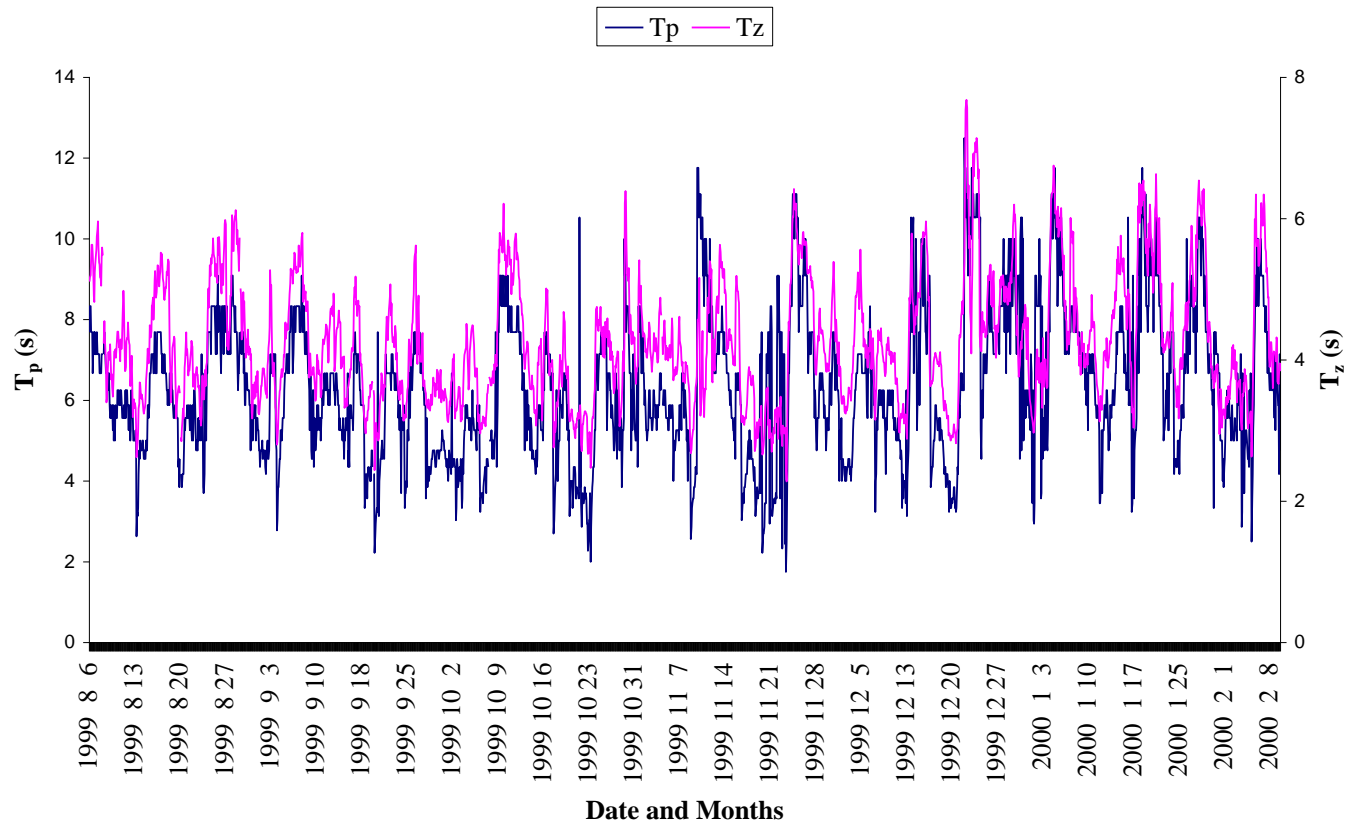

Figure 5: Time series plot of off shore wave peak and zero-crossing periods during the period August 1999 February 2000

The temporal distribution of the off shore surface wave direction and the wind direction during the study period was depicted in Fig.(6). The correlation coefficient between these two physical parameters was estimated to be only 0.28 . Thus, the direction of propagation of the off shore surface waves in the study area might possibly be controlled by the variations in depth (basin topography), and the Coriolis force rather than the wind direction. While the mean direction of off shore surface wave propagation over the period of Aug-99 tillFeb-00 was $245.8^{\circ} \mathrm{TN}$, the mean wind direction over the same period was $163.7^{\circ} \mathrm{TN}$.The maximum wave height records over the six months of records varied between $0.26 \mathrm{~m}$ and $6.98 \mathrm{~m}$, with an average of $1.6 \mathrm{~m}$ as shown in Fig. (7). The correlation coefficient with the wind speed was 0.71 , which was as high as that of the significant wave height.

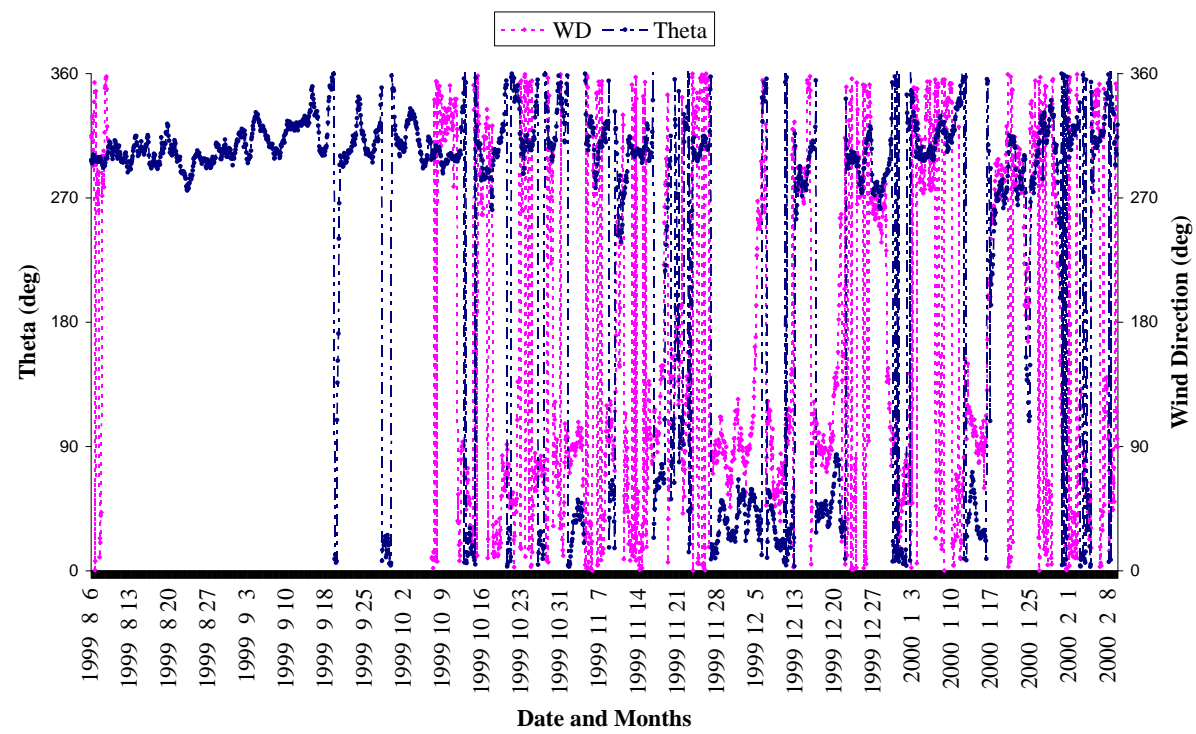

Figure 6: Time series plot of off shore wave direction and wind direction during the period August 1999 February 2000 


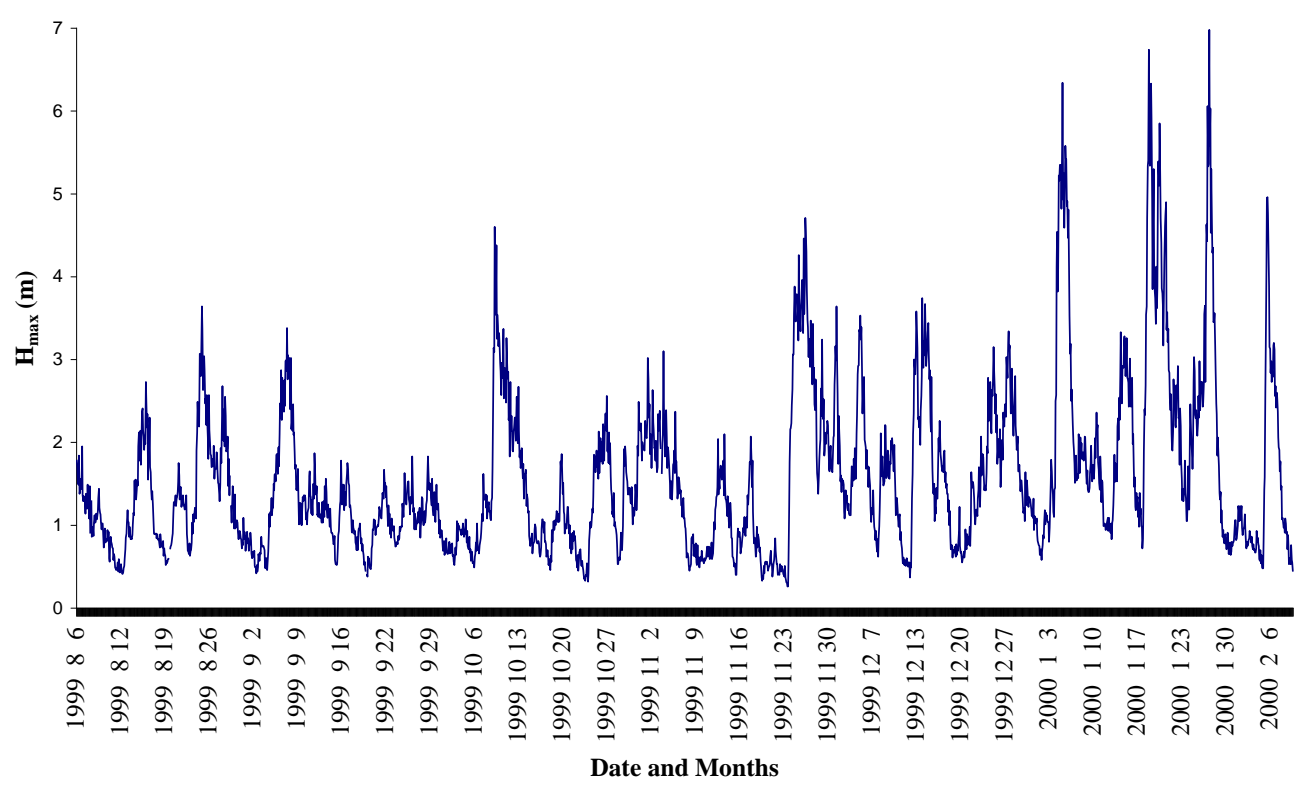

Figure 7: Time series plot of off shore maximum wave height during the period August 1999 - February 2000

From August 1999 to February 2000, $\mathrm{C}_{\max }$ for the off shore surface waves varied between $0.15 \mathrm{~m}$ and $3.64 \mathrm{~m}$ with an average of $0.87 \mathrm{~m}$ as described in Figure (8). The correlation coefficient between $\mathrm{C}_{\max }$ and wind speed is 0.71 , which, again, reflected the strong tie between the two parameters and also reflected the strong impact of wind speed on the variations of the recorded wave heights off the eastern Egyptian Mediterranean coast.

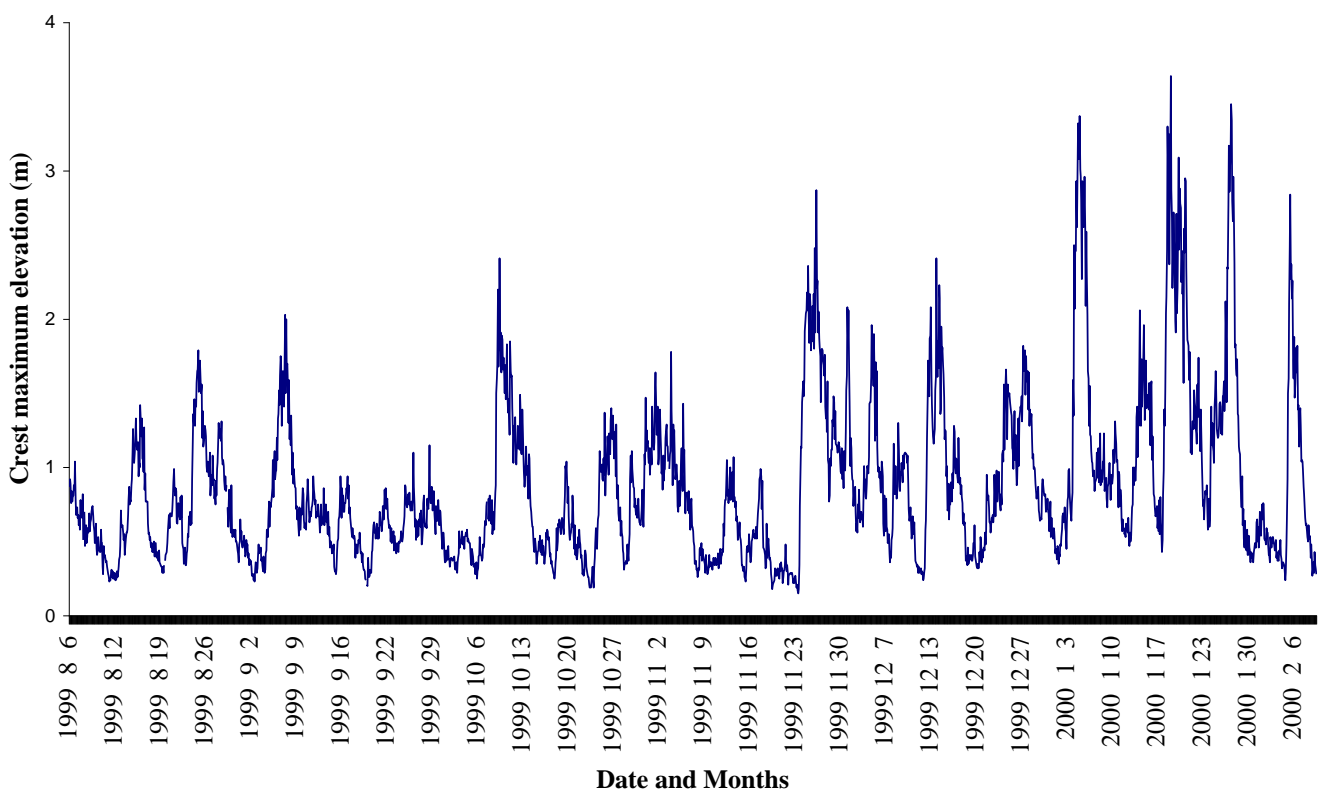

Figure 8: Time series plot of the off shore surface wave maximum crest elevation during the period August 1999 - February 2000

\subsection{Near shore surface waves}

Fig. (9) showed the temporal distribution of $\mathrm{H}_{\mathrm{s}}$ for the near shore surface wavespropagating off Port Said, Egyptduring the period from Aug-99 to Feb-00. Estimates of $\mathrm{H}_{\mathrm{s}}$ varied from a minimum of $0.05 \mathrm{~m}$ to a maximum of $2.36 \mathrm{~m}$, with an average of $0.51 \mathrm{~m}$. The correlation coefficient of the near shore $\mathrm{H}_{\mathrm{s}}$ to the wind speed was 0.53.The temporal distributionforboth near shore $\left(T_{p}\right)$ and near shore $\left(T_{z}\right)$ was depicted in Fig. (10), andmeasurements of $\mathrm{T}_{\mathrm{p}}$ ranged from $3.71 \mathrm{~s}$ to $11.13 \mathrm{~s}$, while measurements of $\mathrm{T}_{\mathrm{z}}$ ranged from $3.85 \mathrm{~s}$ to $8.06 \mathrm{~s}$. Over the six months of investigation, the average $T_{p}$ was $6.3 \mathrm{~s}$, while the average $T_{z}$ was $5.3 \mathrm{~s}$. 


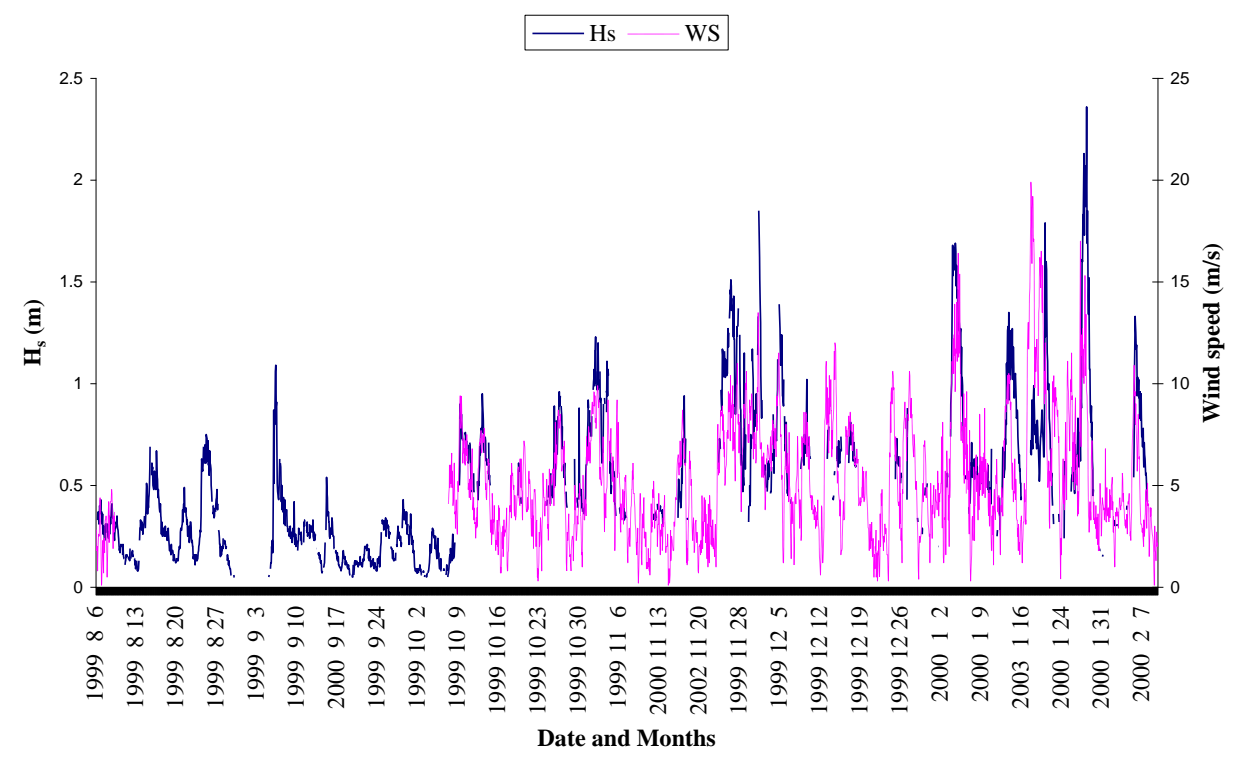

Figure 9: Time series plot of the near shore significant wave height and the wind speed during the period August 1999 - February 2000

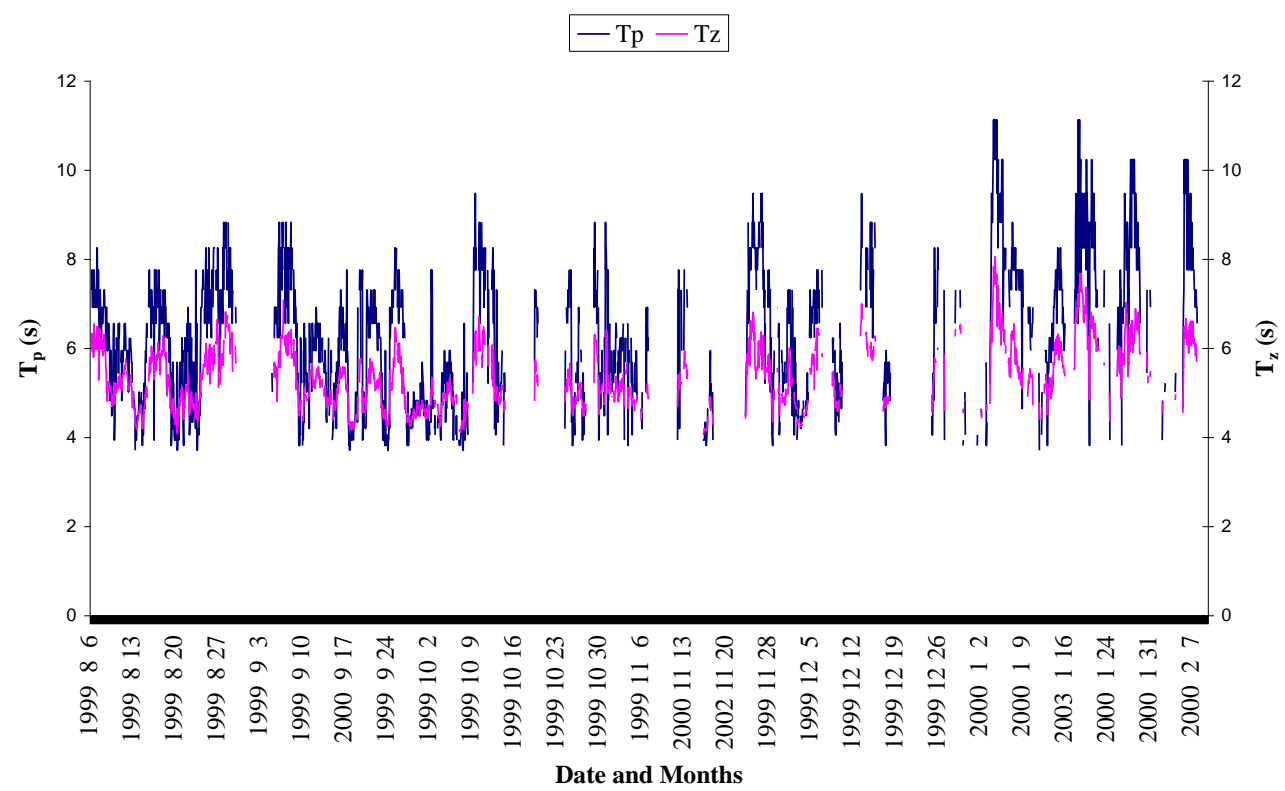

Figure 10: Time series plot of near shore wave peak and zero-crossing periods during the period August 1999 February 2000

\section{Conclusions}

The present study presented a preliminary investigation of the characteristics of off shore and near shore surface waves off Port Said, Egypt. The investigation revealed a weak correlation between the off shore surface waves and wind direction as the correlation coefficient was as low as 0.28 . The mean direction of off shore surface waves, from August 1999 to February 2000, was 245.8 TN, while the mean wind direction over the same period was $163.7^{\circ} \mathrm{TN}$. The study supposed a stronger effect for both the topography (depth variations) and Coriolis force on the propagation of the off shore surface waves rather than the prevailing wind. Both off shore and near shore surface waves were strongly correlated to the wind speed with coefficients of correlation as high as 0.72 and 0.53 respectively. For off shore surface waves, $H_{s}$ ranged from a low of $0.18 \mathrm{~m}$ to a high of $4.07 \mathrm{~m}$, with an average of $1.01 \mathrm{~m}$, while for the near shore surface waves it ranged from $0.05 \mathrm{~m}$ to $2.36 \mathrm{~m}$, with an average of $0.51 \mathrm{~m}$. The study also revealed the existence of a strong tie between the maximum crest elevations of offshore waves and wind speed as the estimated coefficient of correlation was 0.71 , and theaverage $\mathrm{T}_{\mathrm{p}}$ was estimated to be $6.3 \mathrm{~s}$ 


\section{Acknowledgements}

The authors wish to express their thanks and deep appreciation to the Faculty of Science, University of Alexandria, and the National Institute of Oceanography and Fishery, Egypt for providing scientific material and research facilities.

\section{References}

[1] T. M. El-Geziry, I. A. Maiyza, and H. I. Maiyza, General trend of wind anomalies in the south-eastern Mediterranean Sea. Journal of King Abdul-Aziz University (JKAU), Marine Sciences, 24 (2), 2013, 85-97.

[2] T.M. El-Geziry, On the Long term Behavior of Wind-Wave Climatology over the west region of Scotland, U.K., Journal of Renewable Energy and Sustainable Development, 1, 2015, 113-125.

[3] D. Mollison,Assessing the wave energy resource. In: Statistics for Environment 2. Barnett and Turkman Eds. Wiley press, 1994, 205-220

[4] C. G. Soares, On the occurrence of double peaked wave spectra. Journal of Ocean Engineering, 18 (1),1991,167-171.

[5] A .J. Kuik, G. Vledder, L. H. Holthuijsen, A method for the routine analysis of pitch and roll buoy wave data. Journal of Physical Oceanography, 18 (7), 1988, 1020-1034.

[6] L.H. Holthuijsen, Linear wave theory (oceanic waters). In: Waves in oceanic and coastal waters. Cambridge University Press, 2007,106-143

[7] M. M. Amrutha, V. S. Kumar, S. Sharma, J. Singh, R. Gowthaman and R. S. Kankara,Characteristics of shallow water waves off the central west coast of India before, during and after the onset of the Indian summer monsoon. Journal of Ocean Engineering, $107,2015,259-270$.

[8] L. Shuxiua, S. Zhaochena, Z. Yihuia, S. Jiafab, and Z. Yifei, Laboratory Study on the Characteristics of Deep-water Breaking Waves. Journal of Proceeding Engineering, 116, 2015, $414-421$.

[9] M. Zounemat-Kermani and O. Kisi, Time series analysis on marine wind-wave characteristics using chaos theory. Journal of Ocean Engineering, 100, 2015, 46-53.

[10] N. Yilmaz, Spectral characteristics of wind waves. Middle East Technical University, Turkey, 2007.

[11] G. Martucci, S. Carniel, J. Chiggiato, M. Sclavo, P. Lionello and M. B. Galati, Statistical trend analysis and extreme distribution of significant wave height from 1958 to 1999 - an application to the Italian Seas. Journal of Ocean Science, 6, 2010, $525-538$.

[12] G. Reikard and W. E. Rogers, Forecasting ocean waves: comparing a physics-based model with statistical models. Journal of Coastal Engineering, 58, 2011, 409-416.

[13] D. R. Del Balzo, J. R. Schultz, and M. D. Earle,Stochastic time-series simulation of wave parameters using ship observations. Journal of Ocean Engineering, 30, 2003, 1417-1432.

[14] J. D. Agrawal andM. C. Deo, On-line wave prediction. Journal of Marine structures, 15, 2002, 57-74.

[15] G. Galanis, D. Hayes, G. Zodiatis, P. C. Chu, Y. H. Kuo and G. Kallos, Wave height characteristics in the Mediterranean Sea by means of numerical modeling, satellite data statistical and geometrical techniques. Journal of Marine Geophysical Research, 33, 2011,1-15.

[16] O. E. Frihy,M. S. Hassan, E. A. Deabes and A. M. Badr, Seasonal wave changes and the morphodynamic response of the beachinner shelf of Abu Qir Bay, Mediterranean coast, Egypt. Journal of Marine Geology, 247, 2008, 145-158.

[17] M. E. Hereher, Coastal vulnerability assessment for Egypt's Mediterranean coast. Journal of Geomatics, Natural Hazards and Risk, $6(4), 2015,342-355$.

[18] M. M. Iskander, Wave climate and coastal structures in the Nile Delta coast of Egypt. Emirates Journal for Engineering Research, 18 (1), 2013, 43-57. 